\title{
NEW PARADIGM ON SINLAMMIM KAFAH IN ISLAMIC ECONOMICS
}

\author{
Roikhan Mochamad Aziz \\ Ikatan Ahli Ekonomi Islam Indonesia \\ roikhanmochamadaziz@gmail.com
}

\begin{abstract}
The result of this new finding is Kaffah approach in Islamic Economics. The ontology of Kaffah concept is Islam. This conjunction with existing life system in human being, environment, and universe. All creations by God could be pointed as the form of Islam. Islam can be meant as a system with holistic approach, comprehensive view, and Kaffah perspective. Then Islam as a system becomes the root of concept to integrate in economic concept and the epistemology is Kaffah. Then axiology relation has 2 matter representing good and bad. Sinlammim as a methodology can be approached by digital root tool.
\end{abstract}

Keywords: Islamic Economics; Sinlammim Kaffah

\begin{abstract}
Abstrak
Hasil dari temuan ini ialah pendekatan kaffah dalam ekonomi syariah. Ontologi dari konsep kaffah ialah Islam. Hubungan ini terkait dengan kehidupan dari manusia, perilaku, dan alam semesta. Seluruh makhluk hidup ditunjuk oleh Allah sebagai bagian dari Islam. Islam dapat diartikan sebagai suatu sistem dan pendekatan holistik, pendekatan kaffah. Kemudian Islam ialah suatu sistem menjadi akar konsep untuk mengintegrasikan konsep ekonomi dan epistomologi ialah kaffah. Selanjutnya hubungan aksiologi memiliki dua hal yang mewakili kebaikan dan keburukan. Sinlammim merupakan metodologi dapat didekati dengan alat akar digital.
\end{abstract}

Kata Kunci: Ekonomi Syariah; Sinlammim Kaffah 


\section{INTRODUCTION}

In year 2008, world economy is experiencing fundamental change to uncertain economy. This happened to all countries then following into financial crisis. The reason of financial crisis occurred in the world, because current economic system failed to predict the sign of crisis that is knocking over the world. The global crisis has serious disruptions in financial intermediation, access to capital, and price discovery. This condition gave impact to banking sector and all levels of enterprise activity where healthy businesses unable to conduct and finance their commercial activity. Simultaneously with this situation banking sector also got the essential features from this financial crisis by symptoms such as lack of liquidity, no intermediation, asset price deterioration, and capitulation selling. Then, conventional economic and financial science looks for economic model in new paradigm on new approach and more comprehensive.

This matter is conducted to get better solution in face of economics problem. One of the solutions is developing financial system based on interest rate free or without usury which is recognized in Islamic economic concept as profit loss sharing. Islam also has financial system and will be the solution for this situation where economic system is not working properly. This related with the meaning of the word 'Islam'. Islam means safe or consist of solution for all problems. Islam can give contribution to make new paradigm and to solve current world problem by comprehensive approach that recognized in Islam as Kaffah. In other word, Islam has also comprehensive approach.

\section{PHILOSOPHY OF KAFFAH THINKING}

Philosophy of Islamic economics based on three entities which independent but integrate in a system, and there are God, human being, and religion. The principal of Islamic Economics on philosophy determined that human being has been created by God for religious affair ${ }^{7}$. Dimension of this Islamic economics differentiates Islamic from other economic system for instance socialism and capitalism. Philosophy of Islamic Economics relevant paradigm with logical values, aesthetic, and ethical which based on Islam to be benefited among economic behavior of human being. 
In Islam, economic values came from Quran and Hadits in the form of universal principles. While other economic system only focused at causality and positive in an economic activity, Islam preferred to have ethics and values which is implied in economic activity. These values always constitute in every single Islamic economics environment. The big picture of this these is Islamic economics based on Kaffah thinking, which can be labelled as a Kaffah Economics. The appearance of this Kaffah economics concept represents the beginning of whole life system. The ontology of Kaffah concept is Islam. This conjunction with existing life system in human being, environment, and universe. All creations by God could be pointed as the form of Islam.

The word of Islam has root word from 3 initial letters which are alphabet 's' or sin in Arabic (س), alphabet 'l' or lam (ل), and alphabet ' $m$ ' or mim in Arabic (ə). There is sentence in Holy Book from Moslem, Quran, as a ultimate source the meaning of ontology for Islam, that is QS. Ali Imran [3]: verses 19.

\section{EPISTEMOLOGY}

The new concept can be made a Scientific Method if it has fundamental of knowledge according to basic science. One of requisite in philosophy study is epistemology. Epistemology is philosophy branch which study exhaustively the whole process to obtain science. Epistemology intrinsically study about knowledge philosophy which is related to origin of science, how to get knowledge, and validity of thinking. Islam can be meant as a system with holistic approach, comprehensive view, and Kaffah perspective. Then Islam as a system becomes the root of concept to integrate in economic concept which is called Kaffah. Kaffah Economics emerges in epistemology based on the argument that all concept of basic life is Islam which is considered as a system. This epistemology can be found in a sentence of Quran Surah AlBaqarah [2]: verses 208,:

\section{AXIOLOGY}

Studying about epistemology is not enough, without describing its axiology. In consequence of Islamic epistemology, there has to involve a picture of axiology. Analysis in Islamic economics for axiology explains about economic in values and benefit of the knowledge. Human being will not 
conduct something without involving factor of advantages and disadvantages. Function of epistemology in Kaffah Economics made axiology in the form of equilibrium for human real life. Begin with ontology as Islam for the fundamental of life including economics, then epistemology as Kaffah for economic system, and then axiology in the form of economic application such as good and bad for balance. In this axiology relation has 2 matter representing good and bad. The existence of Islam can be done by Kaffah concept. The equilibrium between well and ugly can be read in QS. Saba [34]: verses 28 which expressed 2 matter that is "carrier of good news and giver of commemoration"

\section{METHODOLOGY OF SINLAMMIM}

Kaffah thinking based on above 3 science philosophy framework. First, ontology made Islam as basic thinking. Second, Kaffah epistemology of Kaffah represented value of science. Third, axiology performed the balance in regard to good and bad. From three framework can be built new paradigm that is Scientific Method of Sinlammim. This methodology can be referred to Quran with words 'Silmi Kâffah', with interpretation the word ' silmi' is derived from letters of sin lam mim.

Scientific method of Sinlammim represents one of the solution to break the stagnation of life in order to solve some elementary problems. Sinlammim is important to become counter balance in overcome basic question of science. This new paradigm in line with growth of human last civilization which already need to look for a middle course of problems in existing economy by having new way theory related to spiritual. From time to time human being wishes better civilization and can answer the basic question of life. One of the example how the methodology in Sinlammim is very simple can be seen on human hand.

Method of Sinlammim can be developed in life for instance economics. First element is God, second element is nature, and third elements is religious service. 


\section{SYSTEM THINKING}

An available approach to study real world is system approach. This system approach, the complex world will be studied in the small unit that represent almost all parts from the complex world. In the system terminology, there is model to draw the real world by taking some representatives data into one simple form. After elements and process parts, then following process can be identified, characterized and the reassembly in a unity of structure to have target and product itself. The definition of system is the part of real world from various elements at particular time and place. This system model include component and process which interact one another base on concept of goal design.

System thinking or kaffah thinking represents approach method that related with other parts in one system, not independent unit, because all elements has connection chain as a part in one whole system. System thinking approach based on environmental elements that related to some objects as a one unity, representing system in some parts, can't be dissociated, and influencing each other. System thinking has new paradigm such as comprehensive solution (by think global, and act local).

Diagram: Kaffah Approach In Islam

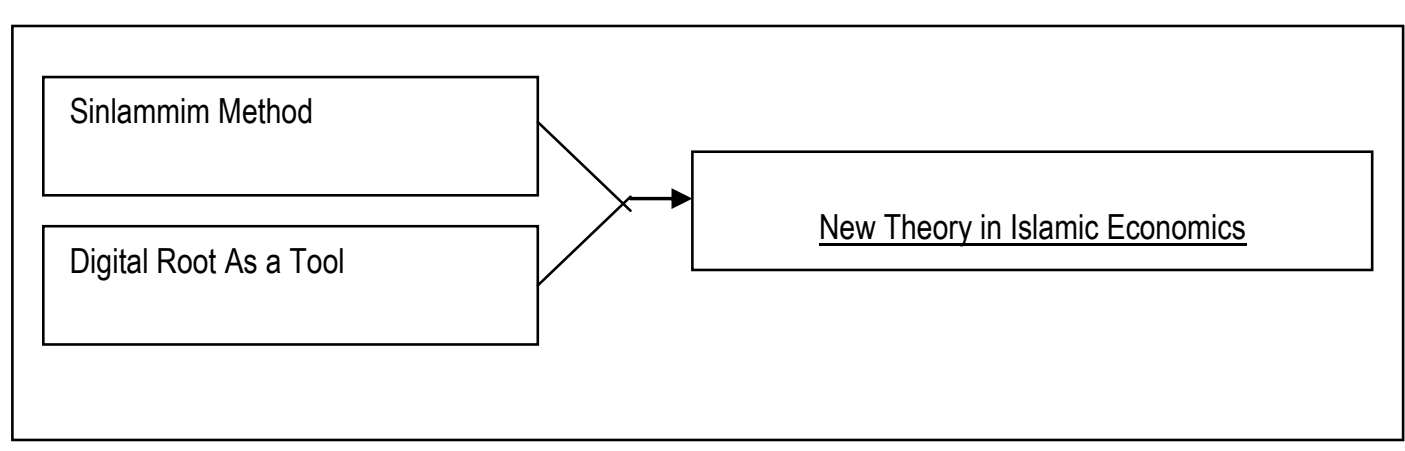

Source: Analysis Result, 2008 In Islam, the concept of system and comprehensive is recognized by word Kaffah.

System thinking or comprehensive approach is independent relation among elements (between object and environment) on dynamic circumstances, non linier, and far from equilibrium with asymmetric 
information. The meaning of comprehensive is to explain system by means totally, there are connections and can't be separately.

During 200 years, since revolution industry in year 1800. The world is dominated by linier thinking concept, extrapolation at 2 points, denying metaphysics element, eliminating $x$ factor, separating between science and religion. This secular concept had been inserted in Adam Smith Theory and Malthus Theory. This theory was representing the approach of economics by linearity the world. For conventional generation, this theory can be adopted in economic system to increase the growth of economy and to support the development performance for the whole world. But in complex world in current situation with world crisis recently, the theory of black box can't become solution to the future of the world.

For example, food for human being, nowadays food is not for human being only. Some food such as CPO has already been consumed by man and also by machine. By this complexity problem, the world need new concept to resolve the complex problem like this. And the world already has waited for third concept, or the end of the day concept, as new paradigm which match with current generation. Forrester from Massachusetts Institute of Technology (MIT) has filled the empty concept by System Dynamics that representing method of System Thinking.Islam scholars are filling the blank of new paradigm with mudharaba concept, and Sinlammim concept, and also other concept.

System Dynamics method becomes new concept to improve an existing theory. And Sinlammim method is new paradigm to have new theory based on al-Quran and Hadis. In the form of pyramid that divided by 3 parts, there are 3 levels of thinking approach to picture assimilation from Islamic concept into system thinking. On the top pyramid shows theory of System Thinking, in the middle of pyramid represents System Dynamics method, and on the ground there is Powersim as a tool. 
Diagram Thinking Concept Between Kaffah And System

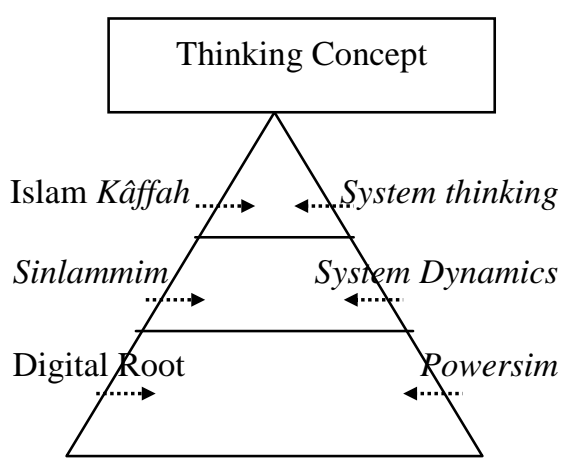

Source: Property Of Owner, DR.IR.H.Roikhan,MA.MM.

For the same pyramid, on the top level there is Islamic theory that called Kaffah Thinking. In the middle represents Sinlammim method, and on the ground shows digital root as a tool.

Positive Causal Loop in Kaffah can be drawn in the sentence of "giving them glad tidings" and Negative Causal Loop can be interpreted as "warning them". So that, for this context, System Thinking can be replaced with Islam Kaffah. For Sinlammim method, as comparator of System Dynamics method, this method also has basic pattern and built by three entities such as 1. God, 2. Human, and 3. Pray. These religious entities can be changed in every particular entity with other illustration for instance:

1. Mother replace God

2. Children replace Human

3. Father replace Pray.

Diagram Comparison Between Kaffah and System
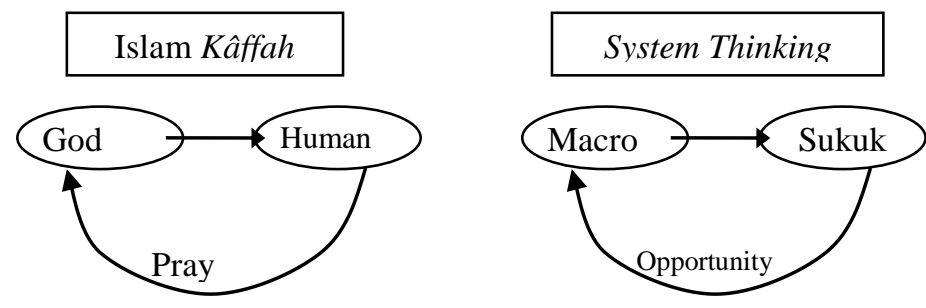

Source: Property Of Owner, DR.IR.H.Roikhan,MA.MM. 
System Dynamics has particular form to be known as feedback. So, System Dynamics and its feedback show this method is a two ways relation. If System Dynamics has two ways relation, so has Sinlammim.

The basic differentiation in System Dynamics can be seen on function of operator and designer. As illustration of operator function is a pilot. Pilot of an airplane can only use all materials in plane system. Pilot only think about how to do the best practice for the part of the system. And who think about the system of the plane?

This is the differentiation System Dynamics: designer is the person to responsible the system of airplane. Designer can create the safety plane and user friendly plane to fly even for younger pilot. Approach in System Dynamics has a deep philosophy to push economic scholar making new model to picture the system of particular economics system. It means in the system thinking, economists always create something new to develop and generate the best model of the economic system. Concept of System Thinking such as System Dynamics method represents more comprehensive approach which is different with an existing methodologies that have been used by researcher and academician for 200 years.

\section{DIGITAL ROOT}

The hegemony of capitalism on science and technology to make a tool in computer such as Powersim that represent one of many tools based on high standard. On the other hand, Islam comes with simple argument and supported by low end technology which can transform the thinking theory of Kaffah into Sinlammim method to have digital root as a tool. In this very easy calculation, the numbers will be count one by one until unlimited amounts on certain repeats numbers on the top of absolute value. Begin with less number until indefinite numbers, there are $1,2,3,4,5,6,7,8,9,10,11,12,13, \ldots$.. etc., so called count numbers. Then these numbers will be summed one by one to get accumulation result to be transformed into digital root. Repeat numbers in digital root table can be grouped in three parts. In this three parts, the repeat numbers has many possible patterns. And one of possible patterns are 319, 
913,616 . This pattern can be grouped by: group one as 319, group two as 913 , and group three as 616 .

Table Digital Root Of Sinlammim

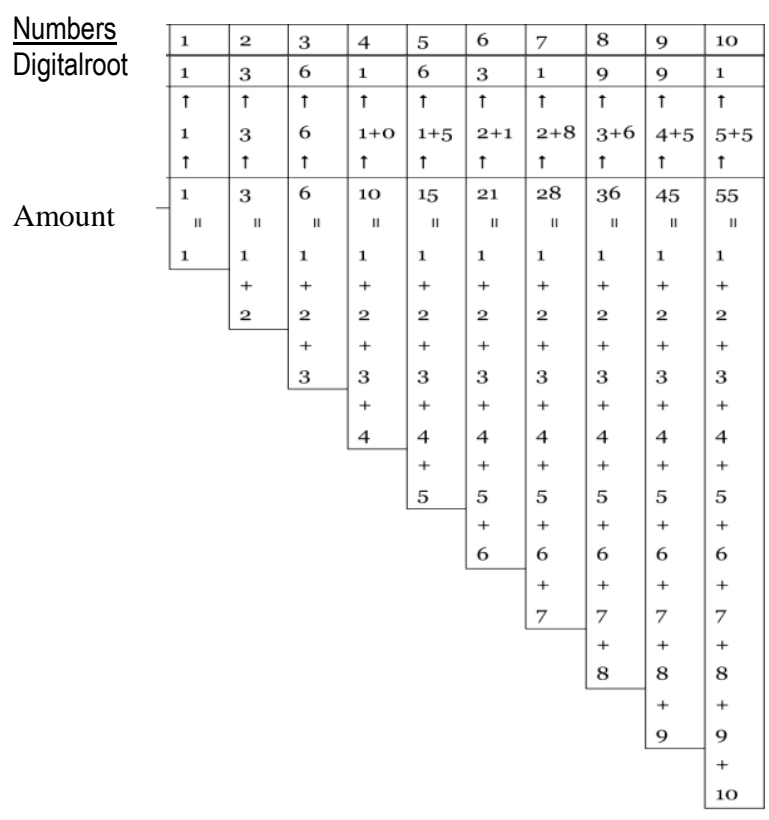

Source: Property Of Owner, Roikhan

The study of Sinlammim method showed that amount of numbers $(1,2,3,4,5,6,7,8,9,10,12,13, \ldots \square \square)$ are representing number which showing evidence the great of Allah (Roikhan Mochamad Aziz. Sinlammim: The God Code. Esa Alam , Jakarta 2006). According to QS. Luqman [31]: 27.

And if all trees on earth were pens and the ocean (were ink) with seven oceans behind it to add to its (supply). Yet would not the Words of Allah be exhausted (In the writing) for Allah is exalted in power, full of wisdom.

Then indefinite number which use all oceans and all forests will back to the highness of Allah. On the other hand, System Dynamics method can fill some weaknesses of orthodox economic theory. During 200 years this conventional theory has been embraced by almost world economists. Collaboration within Sinlammim method and System Dynamics method can be proved as one of concept to solve the problem that is still not answered by conventional economic theories for instance discount rates method and linier thinking method. 


\section{CONCLUSIONS}

System Thinking in Islam is Kaffah Thinking. Kaffah Thinking as a concept has a method. One of methodology in Kaffah concept is Sinlammim method. Islam has big picture to build new paradigm with three basic scientific method. Ontology of economic system is Islam. Epistemology of new system is Kaffah economics. Axiology to implement economics are good and bad.

\section{REFERENCES}

Ali Audah. 2003. Concordance Qur'an. Jakarta: Pustaka Litera.

Mochamad Aziz, Roikhan. 2008. Pemodelan Obligasi Syariah Indonesia Dengan Metode System Dynamics. Dissertation Doctoral Program. School of Postgraduate. State Islamic University (UIN) Syarif Hidayatullah. Jakarta.

Mochamad Aziz, Roikhan. 2008. Analisis Perbandingan Perkembangan Obligasi Syariah Indonesia Dengan Pendekatan System Thinking. Journal Indo Islamika.

Mochamad Aziz, Roikhan. 2007. Analisis Pengembangan Scripless Trading Dalam Sistem Integrasi Pada Lembaga Kliring Penjaminan, Lembaga Penyimpanan Penyelesaian, dan Bursa Efek. Theses Magister Management, University of Indonesia, Jakarta, 1998.

Mochamad Aziz, Roikhan. 1995. Analisis Finansial Pengembangan Angkutan Kereta Api Penumpang di Bandung Selatan. Theses Institute Technology of Bandung, Planning and Civil Technique Faculty, Citiy and Regional Planning Concentration, Bandung.

Mochamad Aziz, Roikhan. 2008 Tinjauan Komparatif Obligasi Syariah Indonesia Pendekatan System Dynamics. Jurnal Ekonomi dan Kemsyarakatan Equilibrium, Vol, 5, No. 2, January-April. 